\title{
Variation in dung beetle (Coleoptera: Scarabaeidae: Scarabaeinae) assemblages in a tropical forest remnant from a Mexican National Park
}

\author{
Gibrán Sánchez-Hernández ${ }^{1,4}$; Benigno Gómez ${ }^{1,5}$; Misraim Edivaldo Rodríguez-López ${ }^{1,6}$, \\ Rolando Antonio Dávila-Sánchez ${ }^{2,7}$ \& Eduardo Rafael Chamé-Vázquez ${ }^{3,8}$ \\ ${ }^{1}$ El Colegio de la Frontera Sur (ECOSUR), Departamento de Conservación de la Biodiversidad. San Cristóbal de Las Casas, Chiapas, México. \\ 2 Environmental Protection \& Control (EPC), Ingeniería Ambiental. Managua, Nicaragua. \\ ${ }^{3}$ El Colegio de la Frontera Sur (ECOSUR), Ecología de Artrópodos y Manejo de Plagas. Tapachula, Chiapas, México. \\ ${ }^{4}$ ORCID: http://orcid.org/0000-0002-0152-1380. E-mail: gisah16@gmail.com \\ ${ }^{5}$ ORCID: http://orcid.org/0000-0002-7260-6744.E-mail: bgomez@ecosur.mx \\ ${ }^{6}$ ORCID: http://orcid.org/0000-0003-3192-5287.E-mail: edivaldo.rguez@gmail.com \\ 7 ORCID: http://orcid.org/0000-0003-3034-1415. E-mail: rdavilas@hotmail.de \\ ${ }^{8}$ ORCID: http://orcid.org/0000-0002-9039-1636. E-mail: echame@ecosur.mx
}

\begin{abstract}
The Cañón del Sumidero National Park (PNCS) is a priority area for conservation, but there are few studies on its fauna, which evidences the need for further basic studies to produce adequate knowledge on its biodiversity. This study aimed to determine dung beetle assemblages temporal distribution, trophic preference, and daily activity patterns. We conducted samplings using baited pitfall traps in a PNCS tropical sub deciduous forest remnant, during the dry and rainy seasons between 2014 and 2015. We captured a total of 863 individuals of 20 species, 12 genera, and five tribes of Scarabaeinae. Estimators suggest that we obtained high faunistic representation (> 80\%), but species richness is low compared to other regional studies. The community was characterized by a high number of rare species and few dominant species. We captured the greatest richness and abundance during rainy months, however, species composition between seasons did not differ significantly. Trophic preference was mainly generalist and we considered only four species as specialists to tapir dung. We observed a clear segregation between activity hours. Nevertheless, we determined only nine species as specialists (six nocturnal and three diurnal) and two others had generalist habits. The low diversity we found could be influenced by the constant pressure of the urban area and non-native species within the park, which alter the dung beetle assemblages. However, performing samplings for longer periods and using a wider range of resources would help us obtain more robust results and better understand species distribution patterns.
\end{abstract}

Keywords. Cañón del Sumidero; Protected area; Sub deciduous forest; Temporal distribution; Trophic preference.

\section{INTRODUCTION}

In Mexico, Natural Protected Areas (NPAs) are zones where the original environments have not been significantly altered by human activities or that need to be preserved and restored. The federal NPAs fall into six categories, which differ among themselves according to their management objectives and the type of zoning they may be subject to. Among them, National Parks are established mainly by their ecosystems scenic beauty and their aptitude for tourism development (Íñiguez et al., 2014).

The Cañón del Sumidero is one of the 67 National Parks decreed in Mexico and the largest of the three located in the state of Chiapas. Due to the hydrological and ecological processes that are developed and the biological diversity that sustains it, this park was integrated to the wetlands of international importance or RAMSAR sites. Besides, it is part of a priority terrestrial region for the regional conservation of birds (CONANP, 2012). To create joint strategies for the conservation of biodiversity and sustainable development at the regional level, this National Park is considered along with the federal NPAs Selva El Ocote Biosphere Reserve (REBISO) and the Villa Allende Natural Resources Protection Area (APRNFVA), as well as two state protection areas (La Pera and Cerro Meyapac), as part of the natural corridor so- 
called Complejo Selva Zoque of Natural Protected Areas (RAC, 2015).

Following the deforestation trend of tropical areas, for almost two decades, this protected area's original vegetation has been subjected to a series of pressures caused by human activities, which reduced it to small remnants and caused irreversible losses in the richness of their flora and fauna (CONANP, 2012). Despite this reserve's relevance, and the importance of knowing its biodiversity, the park's faunistic knowledge is restricted to the study of some groups of terrestrial (Ramírez-Albores, 2010; Altamirano \& Ramírez-Mota, 2013; Chacón et al., 2013) and aquatic vertebrates (Velázquez-Velázquez et al., 2014), disregarding other taxa with bioindicator potential, as occurs with several invertebrate groups, mainly insects (Gerlach et al., 2013).

The dung beetles of the subfamily Scarabaeinae (Coleoptera: Scarabaeidae) are abundant insects in tropical ecosystems that come to occupy diverse types of biomes and altitudes higher than 3,000 meters above sea level (Morón, 2003). They are also important soil entomofauna's components, they are well defined from the taxonomic and functional point of view, and the methods for their sampling are standardized (Spector, 2006), which is why they are considered one of the most convenient groups for the monitoring of biological diversity (Halffter \& Favila, 1993).

In addition to their utility as bioindicators, dung beetles play a fundamental role in eliminating and recycling organic matter. They use both the carrion in different stages of decomposition and the dung of different vertebrates, mainly mammals, to feed and nest (Halffter \& Edmonds, 1982). These organisms perform a series of ecological functions, ranging from the secondary seed dispersal to the nutrient cycle and the suppression of parasites. Many of these functions result in valuable ecosystem services, such as biological control of pests and soil fertilization, so that habitat alteration can interrupt many of the functions in which dung beetles are involved (Nichols et al., 2008). Therefore, this study aimed to analyze the dung beetles assemblages and to determine their temporal distribution, trophic preference, and daily activity patterns in a tropical sub deciduous forest remnant within the Cañón del Sumidero National Park (PNCS). This study also represents the first approach to these insects faunal knowledge in this protected area.

\section{MATERIAL AND METHODS}

\section{Study area}

The Cañón del Sumidero National Park is located in the center-west of the state of Chiapas, between the limits of the physiographic regions Central Depression, Central Plateau, and Northern Mountains, with a total extension of 21,789 ha. Its extreme coordinates are between $16^{\circ} 44^{\prime} \mathrm{N}$ to $16^{\circ} 56^{\prime} \mathrm{N}$ and $93^{\circ} 00^{\prime} \mathrm{W}$ to $93^{\circ} 11^{\prime} \mathrm{W}$, with an altitude that varies between 360 and 1,720 $\mathrm{m}$ asl. Among the predominant vegetation types in the region are the deciduous forest, sub deciduous forest, oak forest, xerophilous vegetation, and secondary vegetation (CONANP, 2012). According to the Köppen classification (García, 2004), the weather is warm, sub-humid with rains in summer. According to the historical data of a meteorological station located in the vicinity of the sampling area $\left(16^{\circ} 49^{\prime} 41^{\prime \prime} \mathrm{N}, 93^{\circ} 05^{\prime} 42^{\prime \prime} \mathrm{W}\right)$, the average annual rainfall is $1,000 \mathrm{~mm}$ during the rainy season (May to October) and $200 \mathrm{~mm}$ in the dry season (November to April) (SMN, 2015). For this study, we selected two areas from a tropical sub deciduous forest remnant located in the core zone destined for protection within the park, $3.2 \mathrm{~km}$ north from the Tuxtla Gutiérrez municipality urban area $\left(16^{\circ} 49^{\prime} 40^{\prime \prime} \mathrm{N}, 93^{\circ} 06^{\prime} 09^{\prime \prime} \mathrm{W}\right)$. The sites were separated by an approximate distance of $1 \mathrm{~km}$ (Fig. 1). We established a third sampling area, but most of the traps were looted during each sampling. Therefore, we did not consider them for analysis.

\section{Sampling and identification}

In each of the two sampling areas, we delimited a transect with an approximate length of $500 \mathrm{~m}$. In each transect, we installed eight baited pitfall traps with a minimum separation of $50 \mathrm{~m}$ from each other to promote their statistical independence (Larsen \& Forsyth, 2005). These traps consisted of cylindrical plastic containers of $1 \mathrm{~L}$ capacity ( $11 \mathrm{~cm}$ in diameter, $18 \mathrm{~cm}$ deep) buried at ground level, using ethylene glycol as a preservative liquid. The baits we used were carrion (squid and river fish), or tapir [Tapirus bairdii (Gill, 1865)] and jaguar [Panthera onca (Linnaeus, 1758)] dung. We obtained the last two attractants from specimens of a local zoo, located southeast of Tuxtla Gutiérrez, Chiapas (16 $46^{\circ} 28.8^{\prime \prime} \mathrm{N}$, $\left.93^{\circ} 05^{\prime} 42.1^{\prime \prime} \mathrm{W}\right)$.

We performed the surveys in three months during the rainy season (July and September 2014, and June 2015) and three months during the dry season (December 2014, February and April 2015), which we chose as being representative of each season. The traps were active for two days in each month of sampling and we recovered the samples every $12 \mathrm{~h}$ (7:00 am and 7:00 pm). We conserved the collected individuals in containers with $70 \%$ ethanol, and we identified them with a Stereoscopic microscope Zeiss Stemi 1000, using several taxonomic studies (Kohlmann, 1997; Rivera-Cervantes \& Halffter, 1999; Kohlmann \& Solís, 2001; Génier \& Kohlmann, 2003; Kohlmann \& Solís, 2006; Delgado \& Kohlmann, 2007; Edmonds \& Zidek, 2010, 2012; Chamé-Vázquez et al., 2020).

\section{Data analysis}

We used a species accumulation curve to verify the sampling efficiency for the entire dataset. We calculated the curve using the specaccum function of the Vegan package (Oksanen et al., 2019) in R software version 3.6.2. (R Core Team, 2019). We calculated the non-parametric 


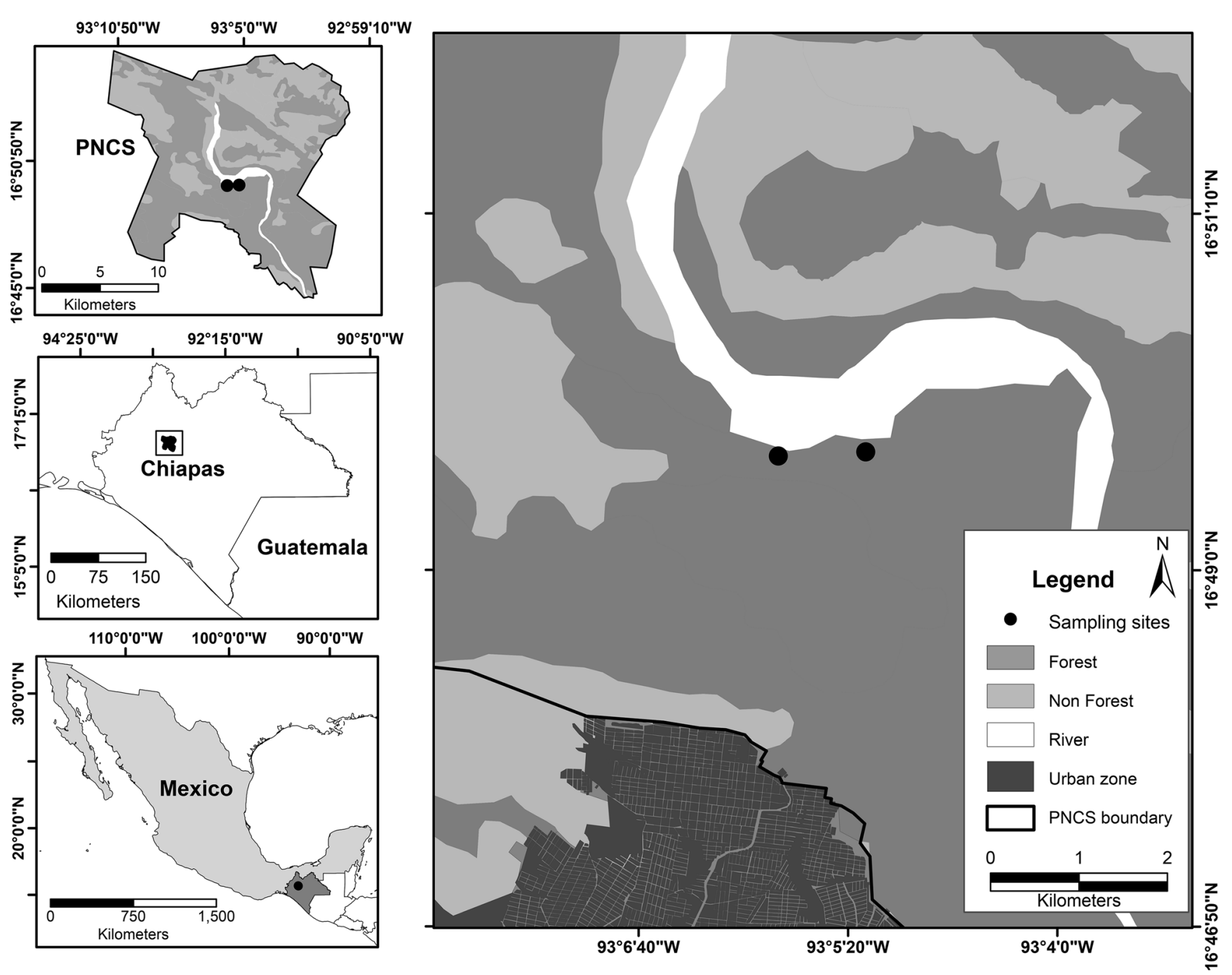

Figure 1. Location of the two sampling areas in a tropical forest remnant in the core zone of the Cañón del Sumidero National Park, Chiapas.

richness estimators Chao 1, ICE, Bootstrap, and MichaelisMenten to determine the number of expected species, using EstimateS software version 9.1 (Colwell, 2013). We determined the precipitation effect on species richness and abundance through the Pearson's correlation coefficient using the $\mathrm{R}$ software ggpubr package (Kassambara, 2019). To visualize the dominant species in each of the used attractants, we made rank-abundance curves by transforming the relative abundances $\left(\log _{10}+1\right)$ of each species. We used a non-Metric Multidimensional Scaling (NMDS) to represent the grouping patterns in the species composition between sampling seasons, baits, and daily activity. We also carried out an analysis of similarity (ANOSIM test) to verify the differences in the dung beetle species composition between these same comparisons. We performed these analyzes with abundance data using the Bray-Curtis dissimilarity index in the PAST software version 3.26 (Hammer et al., 2001).

We determined the species' preference towards any of the four baits used following the method proposed by Halffter \& Arellano (2002), considering that the species were specialists for a given resource when its occurrence was $\geq 80 \%$ in one of the four baits used. For this analysis, we excluded those species represented by less than five individuals (rare species) to avoid aggregation by inclusion. According to their activity hours, we tested the species' classification with the multinomial model (CLAM-test) developed by Chazdon et al. (2011), which is considered adequate for species classification when the sample size is small. This model allowed us to determine a statistical association of preferences (specialists and generalists) in two distinct categories (i.e., diurnal and nocturnal) based on the species' relative abundance. We performed this analysis in the CLAM program version 1.0 (Chao \& Lin, 2011) using the supermajority specialization limit $(k=0.667)$ and a significance level of 0.05 .

\section{RESULTS}

We captured a total of 863 individuals of 20 species and 12 genera grouped into five tribes of the subfamily Scarabaeinae (Table 1). The tribes with the most significant number of species were Coprini and Deltochilini, both with four species. Canthon and Onthophagus were the genera with the highest number of species registered with three species each. Ateuchus rodriguezi (Preudhomme de Borre, 1886) ( $\mathrm{n}=212)$, Uroxys microcularis Howden \& Young, 1981 ( $\mathrm{n}=198$ ), Copris laeviceps Harold, 1862 ( $\mathrm{n}=174)$, and Canthon vazquezae 
Table 1. Dung beetle species composition and their abundances in two sampling seasons in a forest remnant of the Cañón del Sumidero National Park, Mexico. DA $=$ daily activity; $D=$ diurnal; $N=$ nocturnal; $G=$ generalist; $R=$ too rare.

\begin{tabular}{|c|c|c|c|c|c|c|c|c|}
\hline \multirow{2}{*}{ Tribes/Species } & \multicolumn{3}{|c|}{ Rainy season } & \multicolumn{3}{|c|}{ Dry season } & \multirow{2}{*}{ Total } & \multirow{2}{*}{ DA } \\
\hline & Jul14 & Sep14 & Jun15 & Dec14 & Feb15 & Apr15 & & \\
\hline \multicolumn{9}{|l|}{ Tribe Ateuchini } \\
\hline Ateuchus rodriguezi (Preudhomme De Borre) & 50 & 125 & 32 & 5 & - & - & 212 & $\mathrm{~N}$ \\
\hline Scatimus ovatus Harold & 1 & - & 9 & - & - & - & 10 & $\mathrm{~N}$ \\
\hline Uroxys microcularis Howden \& Young & 48 & 34 & 112 & 2 & 1 & 1 & 198 & $\mathrm{~N}$ \\
\hline \multicolumn{9}{|l|}{ Tribe Coprini } \\
\hline Canthidium centrale (Boucomont) & 2 & - & - & - & - & - & 2 & $\mathrm{R}$ \\
\hline Canthidium pseudoperceptibile Kohlmann \& Solís & - & - & 1 & - & - & 1 & 2 & $\mathrm{R}$ \\
\hline Copris laeviceps Harold & 14 & 122 & 5 & 25 & 8 & - & 174 & N \\
\hline Copris lugubris Boheman & - & 1 & - & - & - & - & 1 & $\mathrm{R}$ \\
\hline Dichotomius amplicollis (Harold) & 2 & - & 3 & - & - & - & 5 & $\mathrm{~N}$ \\
\hline \multicolumn{9}{|l|}{ Tribe Deltochilini } \\
\hline Canthon cyanellus LeConte & - & 2 & - & - & - & - & 2 & $\mathrm{R}$ \\
\hline Canthon femoralis (Chevrolat) & 12 & 4 & 13 & - & - & - & 29 & $G$ \\
\hline Canthon vazquezae (Martínez, Halffter \& Halffter) & 6 & 134 & 18 & 1 & - & - & 159 & D \\
\hline Deltochilum sublaeve (Bates) & - & 1 & - & - & - & - & 1 & $\mathrm{R}$ \\
\hline Deltochilum scabriusculum Bates & 8 & 4 & 5 & - & - & - & 17 & $\mathrm{~N}$ \\
\hline \multicolumn{9}{|l|}{ Tribe Onthophagini } \\
\hline Onthophagus anthracinus Harold & - & - & 1 & - & - & - & 1 & $\mathrm{R}$ \\
\hline Onthophagus guatemalensis Bates & 1 & - & - & - & 7 & - & 8 & D \\
\hline Onthophagus cyanellus Bates & - & - & 1 & 2 & 3 & - & 6 & D \\
\hline \multicolumn{9}{|l|}{ Tribe Phanaeini } \\
\hline Coprophanaeus corythus (Harold) & 2 & - & - & - & - & - & 2 & $\mathrm{R}$ \\
\hline Phanaeus demon Laporte-Castelnau & - & - & 1 & - & - & - & 1 & $\mathrm{R}$ \\
\hline Phanaeus endymion Harold & 13 & 6 & 12 & - & - & - & 31 & $G$ \\
\hline Sulcophanaeus chryseicollis (Harold) & 一 & 2 & 一 & 一 & 一 & 一 & 2 & $\mathrm{R}$ \\
\hline Abundance & 159 & 434 & 213 & 35 & 19 & 2 & 863 & \\
\hline Richness & 12 & 11 & 13 & 5 & 4 & 2 & 20 & \\
\hline Seasonal abundance & & & 807 & & & 56 & & \\
\hline Seasonal richness & & & 20 & & & 7 & & \\
\hline
\end{tabular}

(Martínez, Halffter \& Halffter, 1961) ( $\mathrm{n}=159)$ were the most abundant species and represent $86.19 \%$ of the total abundance. On the other hand, Copris lugubris Boheman, 1858, Deltochilum sublaeve Bates, 1887, Onthophagus anthracinus Harold, 1873, and Phanaeus demon Castelnau, 1840, were represented by a single individual.

The species accumulation curve does not tend to stability (Fig. 2), which demonstrates a high probability of encountering other dung beetle species in the area. ICE estimated the maximum number of species $(S=23.7)$, followed by Bootstrap ( $S=22.6)$, Chao $1(S=22)$, and Michaelis-Menten $(S=21.5)$. These values suggest that the effort we invested was adequate to sample a representative percentage of the dung beetle assemblages since it allowed registering between 84.4 and $93 \%$ of the species present in the landscape.

Both richness and abundance varied drastically between sampling seasons, obtaining the highest values during the rainy season. Precipitation presents a significant correlation on abundance $(R=0.99, p=0.0004)$ and a high percentage of correlation but non-significant on species richness $(R=0.81, p=0.053)$. We observed the highest abundance during September $(n=436)$, while June recorded the highest species richness $(s=13)$.

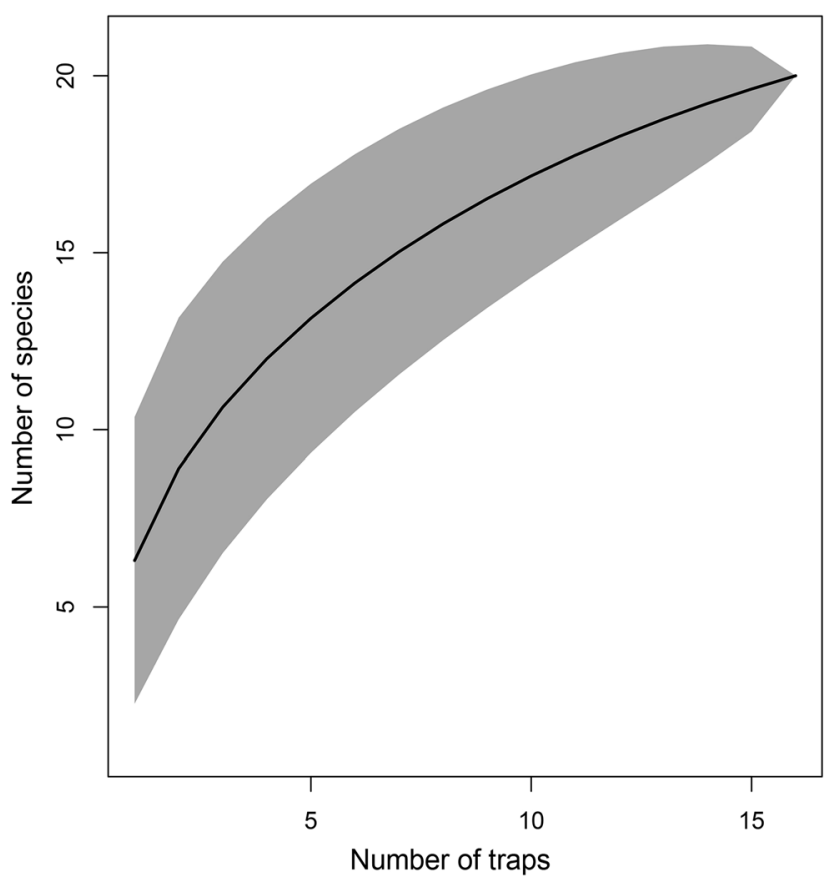

Figure 2. Species accumulation curve of the total richness captured in a tropical forest remnant in the Cañón del Sumidero National Park, Chiapas. 
a)

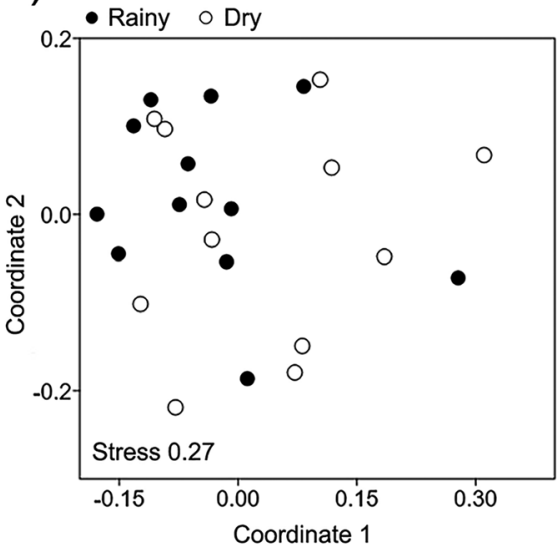

b)

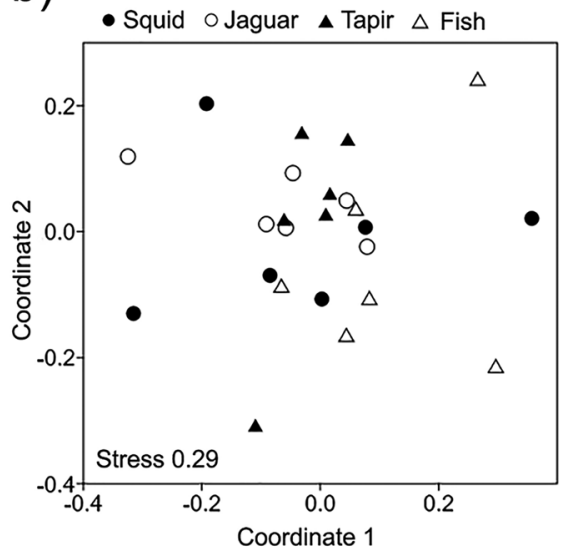

c)

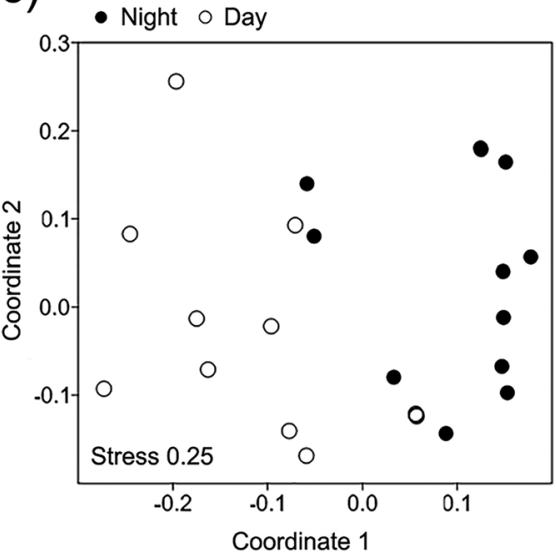

Figure 3. Non-Metric Multidimensional Scaling (NMDS) constructed from the Bray-Curtis index to establish the similarities between (A) seasons, (B) baits, and (C) daily activity of the dung beetle assemblages in the Cañón del Sumidero National Park, Chiapas.

Table 2. Pairwise comparison of species composition between the four baits according to the analysis of similarity (ANOSIM). ${ }^{*}$ Values of $p<0.05$.

\begin{tabular}{ccc}
\hline Pairs of baits & $\boldsymbol{R}$ & $\boldsymbol{p}$ \\
\hline Squid - Jaguar & 0.005 & 0.49 \\
Squid - Fish & -0.06 & 0.59 \\
Squid - Tapir & 0.15 & 0.076 \\
Jaguar - Fish & 0.22 & $0.034^{*}$ \\
Jaguar - Tapir & 0.12 & 0.13 \\
Fish - Tapir & 0.21 & $0.032^{*}$ \\
\hline
\end{tabular}

However, the similarity between both seasons is high, and they do not present statistical differences in the species composition (ANOSIM: $R=0.0787, p=0.26$ ) (Fig. $3 A$ ).

Traps baited with tapir dung captured the greatest species richness and abundance $(S=16, n=573)$, followed by traps baited with jaguar dung $(S=10, n=146)$, fish $(S=10, n=109)$, and squid $(S=8, n=35)$.

We observed no species groupings in the results obtained by the NMDS diagram, which presented a high similarity percentage between baits in a group (ANOSIM: $R=0.1, p=0.061$ ) (Fig. 3B). However, when comparing pairs of baits, we observed statistical differences (Table 2). We determined only four species as tapir dung specialists and considered seven to be generalists (Table 3), while the other nine did not present associations due to their low abundance. Each of the baits presented a different hierarchical order of species, being C. laeviceps the most abundant species in tapir dung, C. vazquezae in jaguar dung, while in squid and fish was A. rodriguezi, but without presenting substantial changes between the four baits' dominant species (Fig. 4). They emphasize C. centrale, C. lugubris, D. amplicollis, O. anthracinus, P. Demon, S. ovatus, and S. chryseicollis as tapir dung exclusive species, $D$. sublaeve jaguar dung exclusive, and C. corythus in fish. We captured five species in all the attractants, and there were no exclusive species in squid.

Regarding daily activity patterns, we found a strong predominance of species with nocturnal habits. We captured 14 species and 625 individuals (72.39\%) at night, and 12 species and 238 individuals (27.61\%) during
Table 3. Trophic preference of dung beetles in a forest remnant of the Cañón del Sumidero National Park, Mexico. JD = jaguar dung; $T D=$ tapir dung; $\mathrm{SQ}=$ squid; $\mathrm{RF}=$ fish.

\begin{tabular}{lcccccc}
\hline \multirow{2}{*}{\multicolumn{1}{c}{ Species }} & $\boldsymbol{n}$ & \multicolumn{6}{c}{ Baits (\%) } & \multirow{2}{*}{ Guild } \\
\cline { 3 - 6 } & & JD & TD & SQ & RF & \\
\hline Ateuchus rodriguezi & 212 & 18.9 & 59.9 & 4.2 & 17 & Generalist \\
Canthon femoralis & 29 & - & $\mathbf{8 6 . 2}$ & 10.3 & 3.5 & Specialist \\
Canthon vazquezae & 159 & 39 & 44.6 & 4.4 & 12 & Generalist \\
Copris laeviceps & 174 & 8 & $\mathbf{8 7 . 4}$ & 1.1 & 3.5 & Specialist \\
Deltochilum scabriusculum & 17 & 11.8 & 70.6 & - & 17.6 & Generalist \\
Dichotomius amplicollis & 5 & - & $\mathbf{1 0 0}$ & - & - & Specialist \\
Onthophagus cyanellus & 6 & 66.7 & - & 33.3 & - & Generalist \\
Onthophagus guatemalensis & 8 & 75 & 12.5 & - & 12.5 & Generalist \\
Phanaeus endymion & 31 & 9.7 & 12.9 & 22.6 & 54.8 & Generalist \\
Scatimus ovatus & 10 & - & $\mathbf{1 0 0}$ & - & - & Specialist \\
Uroxys microcularis & 198 & 6.6 & 79.8 & 2 & 11.6 & Generalist \\
\hline
\end{tabular}

the day, which presents differences in the species composition between both daily activity hours (ANOSIM: $R=0.346, p=0.0001$ ) (Fig. 3C). Meanwhile, $45 \%$ of the species presented a significant association with activity hours (specialists). We determined six species as nocturnal, three as diurnal, two presented generalist habits, and we considered nine too rare to classify (Table 1).

\section{DISCUSSION}

The analysis of the dung beetle assemblages that inhabit the tropical sub deciduous forest remnant studied within the Cañón del Sumidero National Park, Chiapas, indicates that there is a high local faunistic representation, with a sampling effort more significant than $80 \%$, according to the four non-parametric estimators we used. However, the species richness represents only $16.13 \%$ of the dung beetles' species diversity estimated for the state of Chiapas (Sánchez-Hernández \& Gómez, 2018; Sánchez-Hernández et al., 2019a; Chamé-Vázquez et al., 2020), at the same time that it is revealing low species representativeness ( 20 species represented by 863 


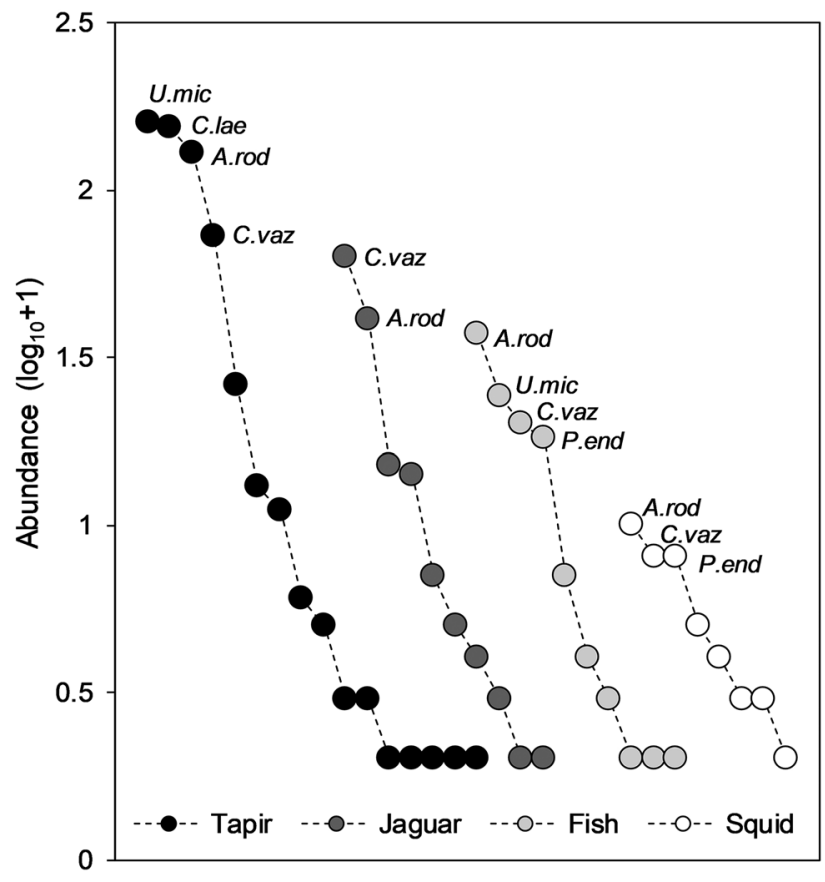

Figure 4. Rank-abundance curves of the dung beetle assemblages collected with four different baits, pointing out the dominant species in each. U.mic $=$ Uroxys microcularis; C.lae = Copris laeviceps; A.rod = Ateuchus rodriguezi; C.vaz. $=$ Canthon vazquezae; P.end $=$ Phanaeus endymion .

individuals) in comparison with other studies conducted in protected areas nearby to the study area. For example, for the Villa Allende Natural Resources Protection Area, Arellano et al. $(2008,2013)$ report between 28 and 33 species, while in the Selva El Ocote Biosphere Reserve, the studies of Gómez et al. (2017), and Sánchez-Hernández et al. (2018), recorded 34, and 37 species, respectively. Differences in these results could be due to the fact that they carried out studies with higher sampling effort and analyzed a variety of habitats with greater spatial and temporal coverage. Another important aspect is that these studies included baits that are considered the most effective for monitoring Scarabaeinae communities (i.e., human feces and domestic pig dung), as they attract almost all of these insects' species compared to other resources regardless of habitat type (Correa et al., 2016; Cajaiba et al., 2017).

Overall, urbanization and other irregular settlements within the reserve have affected around 3,500 ha of the PNCS during the past 20 years (CONANP, 2012). Among the indirect effects of these settlements, densities of feral dogs and cats that have occupied territory within the PNCS drastically alter the wild communities' dynamics, even surpassing the populations of several small and medium mammal species, besides feeding on at least nine native species of the park (Zúñiga \& Sarmiento, 2014). These types of disturbances can also generate alterations in other animal groups, mainly in those that are strongly connected to the presence of mammals, as it is the dung beetles' case (Bogoni et al., 2016), causing species losses locally and imposing barriers to the displacement of individuals, affecting richness, abundance, and the assemblage structure (Andresen \& Laurance, 2007; Nichols et al., 2009; Feer \& Boissier, 2015). This scenario could explain the low faunistic representation at this study's regional scale, as well as the presence of a high proportion of species (45\%) with low abundances and the clear dominance of only four species (Ateuchus rodriguezi, Uroxys microcularis, Copris laeviceps, and Canthon vazquezae) during the study since this is generally indicative of disturbed habitats (Cajaiba et al., 2017; Silva et al., 2017; Sánchez-Hernández et al., 2018).

Despite not presenting apparent differences in the species composition between sampling seasons, we recorded the lowest species richness and abundance during the low rainfall months (December, February, and April). On the contrary, the highest activity expressed with the most significant number of species and individuals was limited to months with adequate environmental conditions, with higher rainfall and stable temperatures. During this season, we captured $93.5 \%$ of the total abundance and all the species reported between the six months of sampling, including 13 exclusive species.

This positive correlation between precipitation levels and the dung beetle assemblages is a typical pattern that has been previously reported in several regions of the Neotropics (Damborsky et al., 2015; Morón-Ríos \& Morón, 2016; Novais et al., 2016; Rodríguez-López et al., 2019). The precipitation creates favorable microclimatic conditions for these organisms' feeding, such as a greater forest cover and ambient humidity that avoid the rapid drying of food, as well as the soil's humidity, which facilitates the reproduction process (Hanski \& Cambefort, 1991). While during the season with low rainfall, the assemblage's dynamics are altered, which is expressed in the decrease of richness and changes in the species structure, mainly due to the low quality and quantity of available trophic resources (Nichols et al., 2009; Damborsky et al., 2015). However, although we did not collect exclusive species during the dry season, we captured a high proportion of individuals of two Onthophagus species during this season's months (December and February) compared to the rainy months. It suggests that performing samplings for longer periods of both seasons can help determine the temporal distribution of dung beetle assemblages adequately.

The dung of Central American tapir (T. bairdii) was the bait that attracted the most significant number of species and individuals (66.34\%), which indicates a solid preference for this resource, being four species (Canthon femoralis, Copris laeviceps, Dichotomius amplicollis, and Scatimus ovatus) defined as specialists in this resource. However, the high percentage of similarity between the composition and the four attractants' species structure added to the non-significant changes among the dominant species suggests that the diet of the dung beetle fauna studied may be more diverse. Other studies that have evaluated the food preference of beetles among a greater variety of feces have shown that the captured species diversity is always higher in the dung of mammals that have an omnivorous feeding than in the dung of herbivores or carnivores (Filgueiras et al., 2009; Bogoni \& Hernández, 2014; Correa et al., 2016). In this way, the inclusion of this type of resource (omnivorous) allows 
each type of attractant to maintain different species composition and potentially induce both the number of specialists and their abundances to increase, modifying, in turn, the composition of generalist species (SánchezHernández et al., 2018). On the contrary, discarding this or another similar attractant would strongly affect the survey results by completely losing a specific community component (Tocco et al., 2018). Therefore, using a greater variety of resources for the sampling of dung beetles (e.g., fruit, fungi, and including different types of carrion and dung) in subsequent studies may help to obtain a more approximate knowledge of the species that inhabit the region. At the same time, it can establish more evident relationships between the amplitude in the use of trophic resources with the abundance and dominance patterns in the dung beetle assemblages (Salomão et al., 2014; Tocco et al., 2018; Sánchez-Hernández et al., 2019b).

Segregation in daily activity patterns plays a vital role in resource partition between the dung beetle species (Hanski \& Cambefort, 1991). Some authors suggest that there are three daily activity schemes (diurnal, nocturnal, and crepuscular) among the beetles of the subfamily Scarabaeinae (lannuzzi et al., 2016), while others indicate that these patterns are narrower, with more specific activity ranges divided only in diurnal and nocturnal (Noriega et al., 2008).

Hernández (2002) indicates that daily activity patterns may be strongly related to elytral coloration. However, other factors in local conditions such as the percentage of forest cover, relative humidity, temperature, availability of resources, and competition, among others, are also determinants in the spatial and temporal distribution of beetles (Hanski \& Cambefort, 1991). Therefore, the distribution during the day can also be more heterogeneous, and there are probably more than two or three daily activity patterns (Feer \& Pincebourde, 2005).

Our data suggest that daily activity hours are pretty similar between species within the same genus or tribe. For example, Ateuchus, Scatimus, Uroxys (Ateuchini), Copris, and Dichotomius (Coprini) are mainly nocturnal, while the Onthophagus species (Onthophagini) are considered diurnal, observing a low percentage of similarity with apparent differences in the species composition between both sampling hours $(p<0.001)$. In this sense, it is possible that most of the Scarabaeinae species resident in the Cañón del Sumidero exhibit these two activity schemes (diurnal-nocturnal), but without being a general rule among the community, as occurs with species like Canthon femoralis and Phanaeus endymion that seem to be adapted to more extreme conditions, whose patterns of distribution during the day are more heterogeneous. These species with daily activity patterns different from most of the community members may have an advantage in occupying dung in nesting sites where their congeners are absent (Niino et al., 2014). It suggests that even at a local level, the assemblages can present more than one representation of activity, and depending on the availability of resources, some species must adapt to these conditions, mainly those that are not dominant.

\section{CONCLUSION}

In summary, we found that the dung beetles species richness in the tropical forest remnant studied was low. At this study scale, the dung beetle community is homogeneous between sampling seasons and the amplitude in the use of trophic resources. The changes between sampling stations do not affect the composition of dung beetle assemblages, and most species seem to present generalist feeding habits. It could respond to the constant expansion of the urban zone adjacent to the reserve (Tuxtla Gutiérrez city) and non-native fauna (feral dogs and cats) within the park.

However, there are some restrictions associated with our study that could limit the generalizability of the findings reported. First, we conducted samplings during short periods of each season (three rainy and three dry months). Therefore, conducting at least one annual sampling cycle will capture a greater species richness and better define the temporal distribution of the assemblages (Rodríguez-López et al., 2019). Second, our study focused only on a small region within the PNCS. It is possible that covering a larger spatial scale and a greater variety of habitats will allow the expansion of captured dung beetle fauna. Finally, although we used several baits for sampling, the inclusion of other attractants would have better defined the extent of resources use that each species can present, and the configuration of guilds would have a different structure. Therefore, these conditions would allow us to obtain more robust results and better understand the spatial and temporal distribution patterns in dung beetle assemblages.

This information represents the first systematic faunistic study concerning dung beetles of the subfamily Scarabaeinae in the Cañón del Sumidero National Park. Intensifying exploration with this and other insect groups in environments characteristic of the reserve and contiguous protected areas, such as tropical deciduous forests, would provide a greater knowledge of the entomofauna at a regional scale. It leads to decision-making tools more adequate to promote conservation, at the same time that greater connectivity can be established between the different protected areas that integrate the Complejo Selva Zoque (Sánchez-Hernández et al., 2020).

\section{ACKNOWLEDGEMENTS}

Ana Gómez Méndez, Erik Hernández Baltazar, and Juan Antonio López provided invaluable assistance during the field work. We thank the Cañon del Sumidero National Park management for all the facilities that allowed us to carry out this research, during which, the park's technical staff provided significant logistical support. We also thank the staff of the Mammals curatorship of the Miguel Álvarez del Toro Zoo (ZooMAT) for allowing us to collect mammal's dung at each sampling. Comments from two anonymous reviewers helped to improve the manuscript. 


\section{AUTHORS' CONTRIBUTIONS}

G.S.H. performed the data analysis; B.G. designed the study; G.S.H., B.G. and M.E.R.L. performed the fieldwork; R.A.D.S. made the map of the study area; E.R.C.M. performed the taxonomic determination of species. All authors wrote and revised the manuscript and gave final approve for publication.

\section{REFERENCES}

Altamirano, M.A. \& Ramírez-Mota, G.M. 2013. Aves del Parque Nacional Cañón del Sumidero y sus alrededores. In: Comisión Nacional para el Conocimiento y Uso de la Biodiversidad (CONABIO) and Gobierno del Estado de Chiapas (Eds.). La biodiversidad en Chiapas: Estudio de Estado. Mexico, CONABI0. v. 2, p. 346-349.

Andresen, E. \& Laurance, S.G. 2007. Possible indirect effects of mammal hunting on dung beetle assemblages in Panama. Biotropica, 39(1): 141-146.

Arellano, L.; León-Cortés, J.L. \& Halffter G. 2008. Response of dung beetle assemblages to landscape structure in remnant natural modified habitats in southern Mexico. Insect Conservation and Diversity, 1(4): 253-262.

Arellano, L.; León-Cortés, J.L.; Halffter, G. \& Montero J. 2013. Acacia woodlots, cattle and dung beetles (Coleoptera: Scarabaeinae) in a Mexican silvopastoral landscape. Revista Mexicana de Biodiversidad, 84(2): 650-660.

Bogoni, J.A. \& Hernández, M.I.M. 2014. Attractiveness of native mammal's feces of different trophic guilds to dung beetles (Coleoptera: Scarabaeinae). Journal of Insect Science, 14(1): 299.

Bogoni, J.A.; Graipel, M.E.; de Castilho, P.V.; Fantacini, F.M.; Kuhnen, V.V.; Luiz, M.R.; Maccarini, T.B.; Marcon, C.B.; Teixeira, C.S.P.; Tortato, M.A.; Vazde-Mello, F.Z. \& Hernández, M.I.M. 2016. Contributions of the mammal community, habitat structure, and spatial distance to dung beetle community structure. Biodiversity and Conservation, 25(9): 1661-1675.

Cajaiba, R.L.; Périco, E.; Dalzochio, M.S.; da Silva, W.B.; Bastos, R.; Cabral, J.A. \& Santos, M. 2017. Does the composition of Scarabaeidae (Coleoptera) communities reflect the extent of land use changes in the Brazilian Amazon? Ecological Indicators, 74: 285-294.

Chacón, E.A.; Riechers, A.; Naranjo, E.J. \& Rivera-Velázquez, G. 2013. Riqueza, abundancia y diversidad de mamíferos silvestres entre hábitats en el Parque Nacional Cañón del Sumidero, Chiapas, México. Therya, 4(3): 647-676.

Chamé-Vázquez, E.R.; Sánchez-Hernández, G. \& Bautista Arredondo E.R. 2020. Presence of Dichotomius (Dichotomius) centralis (Harold) in Mexico and a new state record for Dichotomius amplicollis (Harold) (Coleoptera: Scarabaeidae: Scarabaeinae). The Coleopterists Bulletin, 74(2): 384-387.

Chao, A. \& Lin, S.-Y. 2011. User's guide for the program CLAM (Classification Method). Available: http://chao.stat.nthu.edu.tw/wordpress/software download/clam. Access: 10/07/2019.

Chazdon, R.L.; Chao, A.; Colwell, R.K.; Lin, S.-Y.; Norden, N.; Letcher, S.G.; Clark, D.B.; Finegan, B. \& Arroyo, J.P. 2011. A novel statistical method for classifying habitat generalists and specialists. Ecology, 92(6): 1332-1343.

Colwell, R.K. 2013. Estimates: Statistical estimation of species richness and shared species from samples. Version 9. Available: http://purl.oclc.org/ estimates. Access: 16/08/2018.

Comisión Nacional de Áreas Naturales Protegidas (CONANP). 2012. Estudio Previo Justificativo para modificar el decreto del Área Natural Protegida Parque Nacional "Cañón del Sumidero". Chiapas, México. Available: https://www.conanp.gob.mx/acciones/consulta. Access: 05/06/2019.
Correa, C.M.A.; Puker, A.; Korasaki, V.; Ferreira, K.R. \& Abot, A.R. 2016. Attractiveness of baits to dung beetles in Brazilian savanna and exotic pasturelands. Entomological Science, 19(2): 112-123.

Damborsky, M.P.; Alvarez-Bohle, M.C.; Ibarra-Polesel, M.G.; Porcel, E.A. \& Fontana, J.L. 2015. Spatial and temporal variation of dung beetle assemblages in a fragmented landscape at eastern humid Chaco. Neotropical Entomology, 44(1): 30-39.

Delgado, L. \& Kohlmann, B. 2007. Revisión de las especies del género Uroxys Westwood de México y Guatemala (Coleoptera: Scarabaeidae: Scarabaeinae). Folia Entomológica Mexicana, 46(1): 1-36.

Edmonds, W.D. \& Zídek, J. 2010. A taxonomic review of the neotropical genus Coprophanaeus Olsoufieff, 1924 (Coleoptera: Scarabaeidae, Scarabaeinae). Insecta Mundi, 0129: 1-111.

Edmonds, W.D. \& Zídek, J. 2012. Taxonomy of Phanaeus revisited: Revised keys to and comments on species of the New World dung beetle genus Phanaeus MacLeay, 1819 (Coleoptera: Scarabaeidae: Scarabaeinae: Phanaeini). Insecta Mundi, 0274: 1-108.

Feer, F. \& Boissier, 0. 2015. Variation in dung beetle assemblages across a gradient of hunting in a tropical forest. Ecological Indicators, 57: 164-170.

Feer, F. \& Pincebourde, S. 2005. Diel flight activity and ecological segregation within an assemblage of tropical forest dung and carrion beetles. Journal of Tropical Ecology, 21(1): 21-30.

Filgueiras, B.K.C.; Liberal, C.N.; Aguiar, C.D.M.; Hernández, M.I.M. \& lannuzzi, L. 2009. Attractivity of omnivore, carnivore and herbivore mammalian dung to Scarabaeinae (Coleoptera, Scarabaeidae) in a tropical Atlantic rainforest remnant. Revista Brasileira de Entomologia, 53(3): 422-427.

García, E. 2004. Modificaciones al sistema de clasificación climática de Köppen. 5. ed. Mexico, Instituto de Geografía, Universidad Nacional Autónoma de México.

Génier, F. \& Kohlmann, B. 2003. Revision of the Neotropical dung beetle genera Scatimus Erichson and Scatrichus gen. nov. (Coleoptera: Scarabaeidae: Scarabaeinae). Fabreries, 28(2): 57-111.

Gerlach, J.; Samways, M. \& Pryke, J. 2013. Terrestrial invertebrates as bioindicators: an overview of available taxonomic groups. Journal of Insect Conservation, 17(4): 831-850.

Gómez, B.; Pozo, C.; De la Mora-Estrada, L.F.; Domínguez, M.; RodríguezLópez, M.E. \& Ruiz-Montoya, L. 2017. Diversidad de insectos colectados en cuatro localidades de la Reserva de la Biosfera Selva El Ocote. In: RuizMontoya, L.; Álvarez-Gordillo, G.; Ramírez-Marcial, N. \& Cruz-Salazar, B. (Eds.). Vulnerabilidad social y biológica ante el cambio climático en la Reserva de la Biosfera Selva El Ocote. Mexico, El Colegio de la Frontera Sur, Chiapas. p. 171-254.

Halffter, G. \& Arellano, L. 2002. Response o dung beetle diversity to humaninduced changes in a tropical landscape. Biotropica, 34(1): 144-154.

Halffter, G. \& Edmonds, W.D. 1982. The nesting behavior of dung beetles (Scarabaeinae): An ecological and evolutive approach. Mexico, Instituto de Ecología.

Halffter, G. \& Favila, M.E. 1993. The Scarabaeinae (Insecta: Coleoptera) an animal group for analyzing, inventorying and monitoring biodiversity in tropical rainforest and modified landscapes. Biology International, 27: 15-21.

Hammer, 0.; Harper, D.A.T. \& Ryan, P.D. 2001. PAST: Paleontological statistics software package for education and data analysis. Paleontologia Electronica, 4(1): 1-9.

Hanski, I. \& Cambefort, Y. 1991. Dung Beetle ecology. New Jersey, Princeton University Press, Princeton.

Hernández, M.I.M. 2002. The night and day of dung beetles (Coleoptera: Scarabaeidae) in the Serra do Japi, Brazil: elytra colour related to daily activity. Revista Brasileira de Entomologia, 46(4): 597-600.

lannuzzi, L.; Salomão, R.P.; Costa, F.C. \& Liberal, C.N. 2016. Environmental patterns and daily activity of dung beetles (Coleoptera: Scarabaeidae) in the Atlantic Rainforest of Brazil. Entomotropica, 31(23): 196-207. 
Îniguez, L.I.; Jiménez, C.L.; Sosa, J. \& Ortega-Rubio, A. 2014. Categorías de las áreas naturales protegidas en México y una propuesta para la evaluación de su efectividad. Investigación y Ciencia, 60: 64-70.

Kassambara, A. 2019. ggpubr: 'ggplot2' based publication ready plots version 0.2.4. Available: https://rpkgs.datanovia.com/ggpubr. Access: 27/12/2019.

Kohlmann, B. \& Solís, A. 2001. El género Onthophagus (Coleoptera: Scarabaeidae) en Costa Rica. Giornale Italiano di Entomologia, 49(9): 159-261.

Kohlmann, B. \& Solís, A. 2006. El género Canthidium (Coleoptera: Scarabaeidae) en Norteamérica. Giornale Italiano di Entomologia, 52(11): 235-2295.

Kohlmann, B. 1997. The Costa Rican species of Ateuchus (Coleoptera: Scarabaeidae). Revista de Biología Tropical, 44(3) 45(1): 177-192.

Larsen, T.H. \& Forsyth, A. 2005. Trap spacing and transect design for dung beetle biodiversity studies. Biotropica, 37(2): 322-325.

Morón, M.A. 2003. Antecedentes. In: Morón, M.A. (Ed.). Atlas de los escarabajos de México (Coleoptera: Lamellicornia): Familias Scarabaeidae, Trogidae, Passalidae y Lucanidae. Barcelona, Argania Editio. v. 2, 11-18.

Morón-Ríos, A. \& Morón, M.A. 2016. Evaluación de la fauna de Coleoptera Scarabaeoidea en la Reserva de la Biósfera de Calakmul, Campeche, México. Southwestern Entomologist, 41(2): 468-484.

Nichols, E.; Gardner, T.A.; Peres, C.A.; Spector, S. \& The Scarabaeinae Network. 2009. Co-declining mammals and dung beetles: an impeding ecological cascade. Oikos, 118(4): 481-487.

Nichols, E.; Spector, S.; Louzada, J.; Larsen, T.; Amezquita, S. \& Favila M.E. 2008. Ecological functions and ecosystem services provided by Scarabaeinae dung beetles. Biological Conservation, 141(6): 1461-1474.

Niino, M.; Hosaka, T.; Kon, M.; Ochi, T; Yamada, T. \& Okuda, T. 2014. Diel flight activity and habitat preference of dung beetles (Coleoptera: Scarabaeidae) in Peninsular Malaysia. Raffles Bulletin of Zoology, 62: 795-804.

Noriega, J.A.; Cubillos, A.M.; Castañeda, C. \& Sánchez, A.M. 2008. Actividad diaria de colonización del recurso alimenticio en un ensamble de escarabajos coprófagos (Coleoptera: Scarabaeidae) en la Amazonía Colombiana. Acta Biológica Colombiana, 13(3): 73-84.

Novais, S.M.A.; Evangelista, L.A.; Reis-Junior, R. \& Neves, F.S. 2016. How does dung beetle (Coleoptera: Scarabaeidae) diversity vary along a rainy season in a tropical dry forest? Journal of Insect Science, 16(1): 1-6.

Oksanen, J.; Blanchet, F.G.; Friendly, M.; Kindt, R.; Legendre, P.; McGlinn, D; Minchin, P.R.; O'Hara, R.B.; Simpson, G.L.; Solymos, P.; Stevens, M.H.H.; Szoecs, E. \& Wagner, H. 2019. Vegan: community ecology package version 2.5-6. Available: https://cran.r-project.org/web/packages/ vegan/vegan.pdf. Access: 27/12/2019.

Ramírez-Albores, J.E. 2010. Avifauna de sitios asociados a la selva tropical en la depresión central de Chiapas. Acta Zoológica Mexicana (n.s.), 26(3): 539-562.

Red de Asesores Científicos (RAC) 2015. Red de Asesores Científicos del complejo Selva Zoque de Áreas Naturales Protegidas en Chiapas. Complejo Selva Zoque. Available: https://racselvazoque.wixsite.com/racselvazoque/ complejo-selva-zoque. Access: 25/07/2019.

Rivera-Cervantes, L.E. \& Halffter, G. 1999. Monografía de las especies mexicanas de Canthon del subgénero Glaphyrocanthon (Coleoptera: Scarabaeidae: Scarabaeinae). Acta Zoológica Mexicana (n.s.), 77: 23-150.
Rodríguez-López, E.; Sánchez-Hernández, G. \& Gómez, B. 2019. Escarabajos coprófagos (Coleoptera: Scarabaeidae: Scarabaeinae) en la Reserva El Zapotal, Chiapas, México. Revista Peruana de Biología, 26(3): 339-350.

Salomão, R.P.; Lira, A.F.A. \& lannuzzi, L. 2014. Dominant dung beetle (Coleoptera: Scarabaeidae: Scarabaeinae) species exhibit wider trophic niches on fruits, excrement, and carrion, in Atlantic forest, Brazil. The Coleopterists Bulletin, 68(4): 686-688.

Sánchez-Hernández, G. \& Gómez, B. 2018. First precise locality data for Onthophagus atriglabrus Howden and Gill and new state record for Onthophagus anewtoni Howden and Génier (Coleoptera: Scarabaeidae: Scarabaeinae) in Mexico. The Coleopterists Bulletin, 72(4): 873-876.

Sánchez-Hernández, G.; Chamé-Vázquez, E.R. \& Gómez, B. 2019a. Nuevos datos de distribución para escarabajos del estiércol (Coleoptera: Scarabaeidae: Scarabaeinae) en México. Revista Chilena de Entomología, 45(4): 515-519.

Sánchez-Hernández, G.; Agustín-Sánchez, J.; Bueno-Villegas, J. \& Gómez, B. 2019b. Utilizando un recurso inusual: escarabajos del estiércol atraídos a milpiés (Diplopoda: Spirobolida). Revista Peruana de Biología, 26(4): 499-502.

Sánchez-Hernández, G.; Gómez, B.; Chamé-Vázquez, E.R.; RodríguezLópez, M.E. \& Delgado, L. 2020. Current status of dung beetles (Coleoptera, Scarabaeidae, Scarabaeinae) diversity and conservation in Natural Protected Areas in Chiapas (Mexico). Neotropical Biology and Conservation, 15(3): 219-244.

Sánchez-Hernández, G.; Gómez, B.; Delgado, L.; Rodríguez-López, M.E. \& Chamé-Vázquez, E.R. 2018. Diversidad de escarabajos copronecrófagos (Coleoptera: Scarabaeidae: Scarabaeinae) en la Reserva de la Biosfera Selva El Ocote, Chiapas, México. Caldasia, 40(1): 144-160.

Servicio Meteorológico Nacional (SMN). 2015. Estaciones Meteorológicas Automatizadas. Comisión Nacional del Agua. Available: http://smn1. conagua.gob.mx/emas/catalogo. Access: 21/11/2015.

Silva, R.J.; Pelissari, T.D.; Kranski, D.; Canale, G. \& Vaz-de-Mello, F.Z. 2017. Abrupt species loss of the Amazonian dung beetle in pastures adjacent to species-rich forests. Journal of Insect Conservation, 21(3): 487-494.

Spector, S. 2006. Scarabaeine dung beetles (Coleoptera: Scarabaeidae: Scarabaeinae): an invertebrate focal taxon for biodiversity research and conservation. The Coleopterists Bulletin, 60(5 Suppl. S):71-93.

The R Project for Statistical Computing (R Core Team). 2019. R: A language and environment for statistical computing. $R$ Foundation for Statistical Computing. Available: https://www.r-project.org. Access: 27/12/2019.

Tocco, C.; Balmer, J.P. \& Villet, M.H. 2018. Trophic preference of southern African dung beetles (Scarabaeoidea: Scarabaeinae and Aphodiinae) and its influence on bioindicator surveys. African Journal of Ecology, 56(4): 938-948.

Velázquez-Velázquez, E.; Gómez-González, A.E.; Anzueto-Calvo, M.J. \& Villatoro-Álvarez, V.A. 2014. Peces del Parque Nacional Cañón del Sumidero, Chiapas, México. Mexico, Ediciones DeLaurel.

Zúñiga, F.A. \& Sarmiento, Y. 2014. Informe final del Programa de Control de Especies Exóticas Invasoras en el Parque Nacional Cañón del Sumidero. Mexico, Comisión Nacional de Áreas Naturales Protegidas. 